\title{
Application and Prospect of Graphene and Its Composites in Wastewater Treatment
}

\author{
Jingyi Liu ${ }^{1,3}$, Fang Chen ${ }^{1,2,3}$, Qiang Yao ${ }^{* *}$, Yaosheng Sun ${ }^{1,3}$, Wenjian Huang ${ }^{3}$, \\ Rujie Wang ${ }^{3}$, Bailin Yang ${ }^{3}$, Wengang Li ${ }^{1,3}$, Jingyi Tian ${ }^{3}$ \\ ${ }^{1}$ School of Resources and Civil Engineering, Northeastern University, Shenyang, China \\ ${ }^{2}$ Ministry of Education Key Laboratory of Pollution Processes and Environmental Criteria, \\ Nankai University, Tianjin, China \\ ${ }^{3}$ School of Resources and Materials, Northeastern University at Qinhuangdao, Qinhuangdao, China \\ ${ }^{4}$ Ocean College, Hebei Agriculture University, Qinhuangdao, 066004, China
}

Received: 12 November 2019

Accepted: 29 January 2020

\begin{abstract}
Graphene has received extensive attention due to its excellent properties, and is considered to have broad application prospects in the fields of material processing, energy, biomedicine and drug delivery. Recently, graphene and its composite materials have been gradually applied to wastewater treatment. Here, different graphene composites and their properties are outlined. The application of graphene and its composites as adsorbents and catalysts in typical wastewater treatment (such as dye wastewater, heavy-metal wastewater, oily wastewater, refractory organic wastewater) is reviewed. The treatment efficiency and treatment mechanism of different graphene composites are summarized and analyzed. Finally, reasonable comments and suggestions are raised about the existing problems in wastewater treatment applications. And the outlook for and the future development of graphene and its composites were discussed.
\end{abstract}

Keywords: graphene, graphene composites, wastewater treatment, adsorption, catalysis

\section{Introduction}

Graphene successfully stripped for the first time by Ander K. Geimhe and Konstantin S. Novoselov of the University of Manchester in 2004, is a two-dimensional layered novel carbon nanomaterial with hexagonal honeycomb crystal lattice formed by $\mathrm{sp}^{2}$ hybrid orbital [1]. Following zero-dimensional fullerene, onedimensional carbon nanotubes, three-dimensional

*e-mail: chenfangyq@163.com

**e-mail: yytyyq@163.com diamond, graphene fills the gap of two-dimensional carbon materials [2]. Graphene has a unique structure and excellent electrical, optical, thermal and mechanical properties $[3,4]$. It is considered to be a new strategically important material and has received extensive attention in the fields of electronics, medicine, energy and so on [5-8]. Also, graphene has special properties, such as permeability to protons and specific surface area of up to $2630 \mathrm{~m}^{2} \cdot \mathrm{g}^{-1}$ and has been widely used in the field of environmental pollution control $[9,10]$.

However, the extremely strong $\pi-\pi$ stacking and van der Waals forces between the graphene layers cause 
graphene to agglomerate easily in water [11]. This will result in a lower specific surface area than the theoretical value, which will greatly reduce the active sites involved in the catalytic reaction, affecting the adsorption effect and catalytic efficiency [12]. Besides, graphene is often produced as a powder, which makes it difficult to separate, easy to remain in the water, and will cause certain harm to aquatic ecosystems [9, 13]. In order to solve these problems, graphene was modified. It was prepared as composite materials such as a gel, a magnetic material, or was supported on a skeleton material such as a sponge, a ceramsite or a metal material. Graphene oxide is an important graphene derivative having a sheet structure similar to graphene. The traditional methods for preparing graphene oxide include Brodie method, Staudenmaier method and Hummers method [14]. The carbon atoms in graphene oxide are modified by a large number of oxygencontaining groups, which makes graphene oxide have good dispersibility and reaction activity. These oxygencontaining groups provide active sites for the graphene oxide to be further modified by the introduction of new functional groups [15]. Therefore, it has been widely used in energy storage materials, catalysis, pollutant removal, sensors and other fields, showing an excellent prospect. A large number of studies have shown that due to the special structural characteristics of graphene and graphene oxide, they can effectively remove organic and inorganic pollutants such as heavy metals, antibiotics, dyes, etc. in water as adsorbents and catalyst carriers and good treatment effects have been achieved [16-18]. The application and principle of graphene and its composites in water treatment are simply illustrated in Fig. 1.

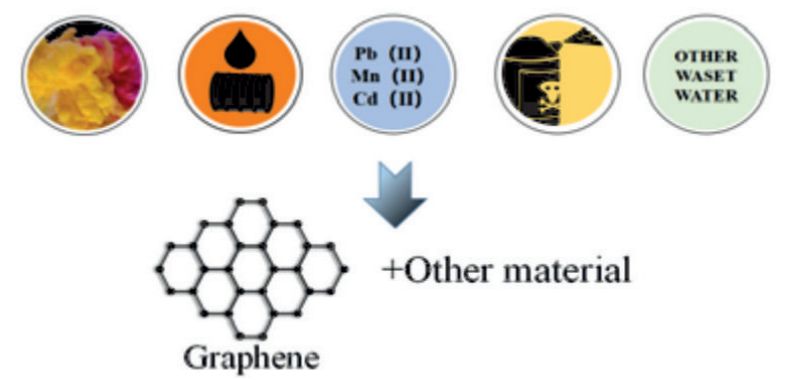

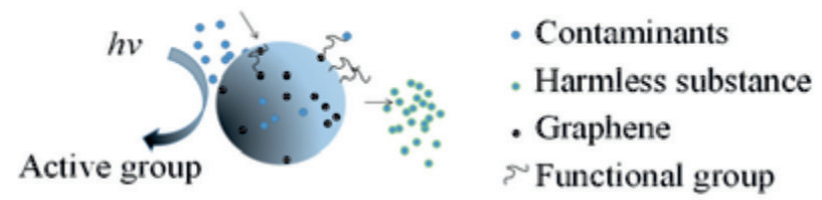

Fig. 1. Application of graphene and its composites in wastewater treatment.

\section{Application of Graphene and Its Composites as Adsorbents in Wastewater Treatment}

Adsorption with the advantages of simple operation, high efficiency, no secondary pollution, low investment cost, and so on, is one of the widely used methods in the field of sewage treatment. The good effects have been achieved in the pollution control of organic matter, heavy metals, radioactive and other pollution in water [19]. The mechanisms include exchange adsorption, physical adsorption and chemical adsorption [20]. Graphene and its composite materials have a large specific surface area, so they are widely used as adsorbents to treat dyes, oils and heavy metal's wastewater. Table 1 summarizes the preparation methods and properties of graphene and its composites as adsorbents.

\section{Dye Wastewater}

Dye is widely used in industrial production of cosmetics, textiles, leather, etc. And dyes are used in large quantities and wide varieties. About $10 \%$ to $20 \%$ of the dyes are discharged with production wastewater during use [21]. Dye wastewater has the characteristics of complex composition, deep color, low biodegradability and biologic toxicity. Currently, commonly used dye wastewater treatment methods include biological treatment, chemical oxidation, photocatalytic degradation, and adsorption [22]. The treatment of dye wastewater by adsorption has become the focus of research because of its many advantages.

At present, the macroscopic of nano-materials is currently the trend of nanotechnology development, and also promotes the effective separation and practical application of nano-adsorbed materials in water. Graphene aerogel (GA) is a three-dimensional porous network structure mainly composed of graphene. It has the nano-properties of graphene and the macrostructure of aerogel [23]. GA not only has the excellent properties of graphene but also solves the problem that graphene is easy to agglomerate and improves the adsorption performance of graphene. Long Chen et al. [24] first prepared agar/graphene oxide (AGO) composite aerogel using a vacuum freeze-drying method as an adsorbent to treat methylene blue (MB) dye wastewater, and the adsorption capacity can reach $578 \mathrm{mg} \cdot \mathrm{g}^{-1}$. Studies have shown that AGO has excellent regeneration property after repetitious adsorption and desorption. Moreover, AGO has large adsorption capacity and is easy to be separated, which is an important direction for the development of graphene composites.

Polysaccharide materials are excellent adsorbents with rich hydroxymethyl, hydroxy and carboxyl groups. Natural polysaccharides k-carrageenan and tragacanth have certain adsorption capacity and high biodegradability, which are non-toxic and low cost. Meiling Yang et al. [25] prepared k-carrageenan/ graphene oxide gel beads (k-Car/GO GBs) using 
Table1. Graphene and its composite as adsorbents.

\begin{tabular}{|c|c|c|c|c|}
\hline Adsorption Materials & Preparation & Contaminant & Adsorption capacity & Ref \\
\hline $\begin{array}{c}\text { Agar/ Graphene oxide (GO) composite } \\
\text { aerogel }\end{array}$ & Vacuum freeze-drying method & Methylene blue & $578 \mathrm{mg} \cdot \mathrm{g}^{-1}$ & {$[24]$} \\
\hline k-carrageenan/GO gel beads & Simple dropping method & Methylene blue & $628.93 \mathrm{mg} \cdot \mathrm{g}^{-1}$ & {$[25]$} \\
\hline \multirow{2}{*}{$\begin{array}{c}\text { New magnetic hydrogel beads } \\
\text { biosorbent }\end{array}$} & \multirow{2}{*}{ Gelation method } & Crystal purple & $94.0 \mathrm{mg} \cdot \mathrm{g}^{-1}$ & \multirow{2}{*}[28]{} \\
\hline & & Congo red & $101.74 \mathrm{mg} \cdot \mathrm{g}^{-1}$ & \\
\hline $\begin{array}{l}\text { Additive-free three-dimensional } \\
\text { graphene aerogel }\end{array}$ & Directional-freezing method & $\begin{array}{l}\text { Various oils and } \\
\text { organic solvents }\end{array}$ & $\begin{array}{c}120 \text { to } 200 \text { times of } \\
\text { its own mass }\end{array}$ & {$[30]$} \\
\hline $\begin{array}{l}\text { Melamine sponge (MS)/Reduced } \\
\text { graphene oxide (RGO) }\end{array}$ & $\begin{array}{l}\text { Skeleton of sponge substrates coated } \\
\text { with uniform graphene }\end{array}$ & Crude oil & About 1500 mg(a) & {$[31]$} \\
\hline Modified cellulose / graphene aerogel & Chemical vapor deposition of CGAs & $\begin{array}{l}\text { Various oils and } \\
\text { organic solvents }\end{array}$ & $\begin{array}{l}80 \text { to } 197 \text { times of } \\
\text { its own mass }\end{array}$ & {$[33]$} \\
\hline \multirow{2}{*}{$\begin{array}{l}\text { Poly (sodium acrylate)-GO } \\
\text { double-network hydrogel }\end{array}$} & \multirow{2}{*}{$\begin{array}{l}\text { Sodium acrylate, methylene bis } \\
\text { acrylamide, ammonium persulfate and } \\
\text { GO are heated in deionized water }\end{array}$} & $\mathrm{Cd}(\mathrm{II})$ & $238.3 \mathrm{mg} \cdot \mathrm{g}^{-1}$ & \multirow{2}{*}[35]{} \\
\hline & & Mn (II) & $165.5 \mathrm{mg} \cdot \mathrm{g}^{-1}$ & \\
\hline $\begin{array}{l}\text { Tetraethylenetetramine/polypyrrole/GO } \\
\text { aerogel }\end{array}$ & $\begin{array}{l}\text { Hydrothermal self-assembly and } \\
\text { freeze-drying technique }\end{array}$ & $\mathrm{Cr}(\mathrm{VI})$ & $408.48 \mathrm{mg} \cdot \mathrm{g}^{-1}$ & {$[36]$} \\
\hline \multirow{2}{*}{ Spongy polysiloxane-GO gel } & \multirow{2}{*}{ Sol-gel method } & $\mathrm{Pb}(\mathrm{II})$ & $256.41 \mathrm{mg} \cdot \mathrm{g}^{-1}$ & \multirow{2}{*}{ [37] } \\
\hline & & $\mathrm{Cd}(\mathrm{II})$ & $136.98 \mathrm{mg} \cdot \mathrm{g}^{-1}$ & \\
\hline \multirow{2}{*}{ Sodium alginate/GO aerogel } & \multirow{2}{*}{$\begin{array}{l}\text { In-situ crosslinking and freeze-drying } \\
\text { methods }\end{array}$} & $\mathrm{Cu}(\mathrm{II})$ & $98.0 \mathrm{mg} \cdot \mathrm{g}^{-1}$ & \multirow{2}{*}[39]{} \\
\hline & & $\mathrm{Pb}(\mathrm{II})$ & $267.4 \mathrm{mg} \cdot \mathrm{g}^{-1}$ & \\
\hline \multirow{2}{*}{ New magnetic biosorbent } & \multirow{2}{*}{ Gelation method } & $\mathrm{Cu}(\mathrm{II})$ & $66.67 \mathrm{mg} \cdot \mathrm{g}^{-1}$ & \multirow{2}{*}[28]{} \\
\hline & & $\mathrm{Pb}(\mathrm{II})$ & $98.0 \mathrm{mg} \cdot \mathrm{g}^{-1}$ & \\
\hline GO/alginate composite membrane & Material liquid is spread on a glass plate & $\mathrm{Pb}(\mathrm{II})$ & $320.51 \mathrm{mg} \cdot \mathrm{g}^{-1}$ & {$[40]$} \\
\hline Sulfonated magnetic GO complex & $\begin{array}{l}\text { Reaction of aryl diazonium salt of } \\
\text { sulfanilic acid with magnetic GO }\end{array}$ & $\mathrm{Cu}$ (II) & $62.73 \mathrm{mg} \cdot \mathrm{g}^{-1}$ & [41] \\
\hline \multirow{3}{*}{ Functionalized magnetic GO } & \multirow{3}{*}{$\begin{array}{l}\text { Mechanically agitating the mixture } \\
\text { of mGO and EDTA dispersions }\end{array}$} & $\mathrm{Cu}$ (II) & $301.2 \mathrm{mg} \cdot \mathrm{g}^{-1}$ & \multirow{3}{*}[42]{} \\
\hline & & $\mathrm{Pb}(\mathrm{II})$ & $508.4 \mathrm{mg} \cdot \mathrm{g}^{-1}$ & \\
\hline & & $\mathrm{Hg}$ (II) & $268.4 \mathrm{mg} \cdot \mathrm{g}^{-1}$ & \\
\hline \multirow{3}{*}{ Layered GO film } & \multirow{3}{*}{ Induce directional flow method } & $\mathrm{Cu}$ (II) & $72.6 \mathrm{mg} \cdot \mathrm{g}^{-1}$ & \multirow{3}{*}{ [43] } \\
\hline & & $\mathrm{Cd}(\mathrm{II})$ & $83.8 \mathrm{mg} \cdot \mathrm{g}^{-1}$ & \\
\hline & & $\mathrm{Ni}(\mathrm{II})$ & $62.3 \mathrm{mg} \cdot \mathrm{g}^{-1}$ & \\
\hline Aminated GO nanosheet & $\begin{array}{l}\text { Combine GO with the aromatic } \\
\text { diazonium salt }\end{array}$ & Co (II) & $116.35 \mathrm{mg} \cdot \mathrm{g}^{-1}$ & {$[44]$} \\
\hline $\begin{array}{l}\text { Sulfuric acid-doped diaminopyridine } \\
\text { polymer }\end{array}$ & Mutual oxidation-reduction technique & Cr (VI) & $609.76 \mathrm{mg} \cdot \mathrm{g}^{-1}$ & {$[45]$} \\
\hline
\end{tabular}

(a) Acities of the MS@RGO monolith $(1.91 \mathrm{~cm} \times 1.82 \mathrm{~cm} \times 1.82 \mathrm{~cm})$ oil absorption. The oil temperature was $95^{\circ} \mathrm{C}$.

a simple dropping method. Scanning Electron Microscope (SEM) showed that the k-Car/GO GBs prepared by this method had more surface wrinkles and pores. The MB has a negatively charged sulfate group, and k-carrageenan is rich in hydroxymethyl and hydroxyl groups, which causes hydrogen bonds and electrostatic interactions to exist between them [26]. At the same time, there is a $\pi-\pi$ stacking interaction between MB molecules and GO [27]. Therefore, the adsorption capacity is significantly higher than that of the pure $\kappa$-carrageenan gel beads ( $\kappa-C a r$ GBs), which can be as high as $628.93 \mathrm{mg} \cdot \mathrm{g}^{-1}$. $\kappa-\mathrm{Car} / \mathrm{GO}$ GBs has good regenerability and is easily separated from water, making it an ideal adsorbent material.

Razieh Sahraei et al. [28] prepared a new magnetic biosorbent hydrogel bead using modified biopolymer tragacanth (GT), polyvinyl alcohol (PVA) and GO in boric acid and acetone solution. The maximum adsorption capacities of cationic dye crystal purple $(\mathrm{CV})$ and anionic dye congo red (CR) can reach 94.0 and $101.74 \mathrm{mg} \cdot \mathrm{g}^{-1}$ respectively. SEM images showed that the composite material after adding GO has a rougher surface than pure GT. Simultaneously, the addition of GO also enhanced the mechanical strength and swelling of GT. The composite has a good regeneration performance. 


\section{Oily Wastewater}

For oily wastewater, the ideal treatment effect is to adsorb the oil without water absorption and to recycle the adsorbed oil [29]. Usually, the oil is removed from the adsorbent by extrusion, which requires the adsorbents to have the hydrophobicity properties, easy separation and anti-extrusion mechanical properties [30-32]. In most cases, the fragile characteristic of graphene aerogels limited their use in the treatment of oily wastewater [30].

To increase the compressive performance of graphene aerogel, Tao Liu et al. prepared an anisotropic, porous structure, highly compressible, additive-free three-dimensional graphene aerogel (AGA) by using anisotropically grown ice crystals as a template to orient the frozen graphene hydrogel [30]. AGA can quickly absorb oil from the water surface for porous structure and hydrophobic properties. The absorption capacity can reach 120 to 200 times of AGA's mass. After absorbing organic liquid, AGA can be regenerated by combustion, distillation, and extrusion. The results show that AGA also has a good adsorption effect on other organic compounds such as ethanol, acetone, $\mathrm{n}$-heptane and n-hexane. At the same time, AGA has the excellent compressive capacity and enables AGA to be used in the wider range of fields.

Cellulose, as a wood derivative, is a low-cost material with a wide range of sources, but the cellulose aerogels usually cannot be regenerated in a dry condition after extrusion. Mi Hao-Yang et al. [33] prepared cellulose/ graphene aerogel (CGAs) by bi-directional freezedrying to produce a special anisotropic aligned porous structure, giving them high compressibility and elasticity. After simple milylation of CGAs by chemical vapor deposition (CVD), the modified cellulose/ graphene aerogel (MCGA) with super-hydrophobicity properties was obtained, and the adsorption capacity of MCGA for oil was 80 to 197 times of its mass. $85 \%$ of the oil could be recovered by mechanical compression for secondary use.

Jing Ge et al. [31] used Joule-heated graphene wrapped sponge (GWS) to process the leaked crude oil in seawater at high speed, and the graphene was uniformly wrapped as a skeleton sponge by centrifugal assisted dip coating. Because of the hydrophobicity of graphene, crude oil can be selectively absorbed into the pores of GWS. At the same time, A voltage was applied to GWS to cause the current to flow through the graphene to generate Joule heat. And the surrounding crude oil was heated to reduce its viscosity, which increases the diffusion coefficient of crude oil in the GWS so that the crude oil in water can be adsorbed quickly, and the crude oil after adsorption can be recycled.

These composite materials of graphene not only have a good effect on wastewater treatment but also do not require high temperature and inert gas protection in the preparation process. Because of their simple preparation process and low cost, these composite materials have broad application prospects in many fields.

\section{Heavy Metal Wastewater}

In the production process of machinery manufacturing, mining, metallurgy, chemical industry, etc. wastewater containing heavy metals will be produced. With the development of industry, heavy metal pollution is becoming more and more serious in water [34]. Heavy metals not only damage the aquatic ecosystems but also seriously harm to the human health. So heavy-metal wastewater treatment has become a hot issue.

Rui Xu et al. [35] prepared a poly(sodium acrylate)graphene oxide (PSA-GO) double-network hydrogel adsorbent for the adsorption of $\mathrm{Cd}(\mathrm{II})$ and $\mathrm{Mn}(\mathrm{II})$ in water with a maximum adsorption capacity of $238.3 \mathrm{mg} \cdot \mathrm{g}^{-1}$ and $165.5 \mathrm{mg} \cdot \mathrm{g}^{-1}$. PSA-GO gel has extraordinary mechanical strength and good reproducibility. Electrostatic adsorption and surface complexation play an important role in the adsorption process. Qianwei Liang et al. [36] obtained a novel nitrogen-doped ultra-light graphene oxide aerogel with three-dimensional (3D) network structure, tetraethylenetetramine/polypyrrole/GO aerogel (TPGA). Polypyrrole and TEPA acted as crosslinkers and provided amino functional groups when TPGA is used to remove $\mathrm{Cr}(\mathrm{VI})$ ions from water. The adsorption capacity of TPGA for Cr (VI) ions was up to 408.48 $\mathrm{mg} \cdot \mathrm{g}^{-1}$ at a $\mathrm{pH}$ of 2.0. The aerogel showed good regenerability and satisfactory recovery of $\mathrm{Cr}$ (VI) ions in actual water samples. A spongy polysiloxanegraphene oxide (PS-GO) gel adsorbent was made by sol-gel method for removing lead and cadmium in wastewater [37]. The maximum adsorption capacity reached $256.41 \mathrm{mg} \cdot \mathrm{g}^{-1}$ and $136.98 \mathrm{mg} \cdot \mathrm{g}^{-1}$, respectively. Moreover, the PS-GO gel adsorbent has remarkable mechanical strength and excellent reproducibility. In the static treatment process, after five cycles, it still maintained a removal efficiency of over $99 \%$. Among the above gel materials, graphene became the main body for adsorption because of the large specific surface area and abundant functional groups. Other materials act as cross-linking agents, making graphene macroscopically avoiding agglomeration of graphene, to make its performance can be fully exerted [38]. Also, the introduction of new functional groups provides more active sites and enhances the adsorption properties of the materials.

In recent years, biopolymers such as sodium alginate have received more and more attention because of their rich functional groups, strong environmental compatibility, good biodegradability and low cost. However, a single biological aerogel has some defects, such as weak mechanical strength and uneven structure. To solve the structural problems, it has become the focus of research adding the fillers to enhance the mechanical strength. Graphene oxide has excellent mechanical 
properties and high adhesion, making it an ideal reinforced filler. Chenlu Jiao et al. [39] prepared ordered porous sodium alginate/graphene oxide (SAGO) aerogel by in-situ crosslinking and freeze-drying methods. Compared with pure sodium alginate aerogel (SA), the SAGO has excellent mechanical strength and elasticity, and its adsorption property is greatly improved. The maximum adsorption capacity for $\mathrm{Cu}$ (II) and $\mathrm{Pb}$ (II) can reach $98.0 \mathrm{mg} \cdot \mathrm{g}^{-1}$ and $267.4 \mathrm{mg} \cdot \mathrm{g}^{-1}$, respectively, which is mainly attributed to the interconnected porous structure and abundant functional groups of SAGO.

In addition to aerogels, graphene oxide can also be prepared into composite membranes for use as adsorbent materials. The maximum adsorption capacity of GO/sodium alginate composite membrane for lead (II) is $320.51 \mathrm{mg} \cdot \mathrm{g}^{-1}$, and the main mechanism of action is physical adsorption [40]. The novel magnetic biosorbent hydrogel bead with a good adsorption effect was prepared by Razieh Sahraei et al. using a wide range of inexpensive biopolymer and graphene oxide with high specific surface area [28]. The maximum adsorption capacities for $\mathrm{Pb}$ (II) and $\mathrm{Cu}$ (II) can reach $81.78 \mathrm{mg} \cdot \mathrm{g}^{-1}$ and $66.67 \mathrm{mg} \cdot \mathrm{g}^{-1}$, respectively.

Adsorb ability of the adsorbent to metal depends on the number and type of functional groups for binding heavy metals. In order to enhance the adsorption performance, it is necessary to introduce some stable functional groups with specific orientation. The sulfonic acid group $\left(-\mathrm{SO}_{3} \mathrm{H}\right)$ is a functional group having excellent adsorption performance, and can form a stable complex with various metal ions. Xinjiang $\mathrm{Hu}$ et al. [41] synthesized sulfonated magnetic graphene oxide complex (SMGO) using p-aminobenzenesulfonic acid. SMGO has good adsorption properties for $\mathrm{Cu}$ (II) and can be easily separated by magnetic separation technique. The research has shown that the functionalized magnetic graphene oxide has good adsorption properties for $\mathrm{Pb}(\mathrm{II}), \mathrm{Hg}(\mathrm{II})$ and $\mathrm{Cu}(\mathrm{II})$, and the magnetic separation can be completed in only 25 seconds [42].

Ping Tan et al. [43] prepared a novel layered graphene oxide film with a large interlayer spacing by inducing directional flow, which has a good adsorption effect on $\mathrm{Cu}(\mathrm{II}), \mathrm{Cd}$ (II) and Ni(II). Fang Fang et al. [44] prepared aminated graphene oxide nanosheet $\left(\mathrm{GO}-\mathrm{NH}_{2}\right)$ by combining graphene oxide with aromatic diazonium salt. The GO-NH$H_{2}$ has a specific surface area of up to $320 \mathrm{~m}^{2} \cdot \mathrm{g}^{-1}$ and excellent adsorption performance. The removal rate of Co (II) exceeded $98 \%$ when the cobaltcontaining wastewater is treated with a membrane made of this material. The adsorption process of the new layered graphene oxide film and $\mathrm{GO}-\mathrm{NH}_{2}$ conforms to the pseudo-second-order kinetics equation, which indicates that chemical adsorption is the main process for controlling the adsorption rate. A variety of groups in the material interact strongly with the adsorbed metal ions through electrostatic and chemical interaction.

The sulfuric acid-doped diaminopyridine polymer was synthesized in situ on the surface of graphene oxide by mutual oxidation-reduction technique, using its large and porous surface as an adsorbent to remove high-concentration $\mathrm{Cr}(\mathrm{VI})$ from water [45]. The removal rate decreases with increasing $\mathrm{pH}$, but the removal rate can still reach $46 \%$ at $\mathrm{pH} 9$. At lower $\mathrm{pH}$ value, the main removal mechanism is the reduction reaction of $\mathrm{Cr}_{2} \mathrm{O}_{7}{ }^{2-}$. At higher $\mathrm{pH}$ value, anion exchange between dopant $\mathrm{SO}_{4}^{2-}$ and $\mathrm{CrO}_{4}^{2-} / \mathrm{Cr}_{2} \mathrm{O}_{7}^{2-}$ was the main removal mechanism. The high concentration of $500 \mathrm{mg} \cdot \mathrm{L}^{-}$ ${ }^{1} \mathrm{Cr}(\mathrm{VI})$ wastewater can be purified in just 100 mins. And the composite has good regenerability.

In summary, the composite materials with the distinct internal structures were prepared using different materials by diverse processes, so that their application ranges and adsorption characteristics were also significantly different. Some graphene composites can achieve satisfactory pollution treatment effects under special conditions, which limited the scope of application of these materials. Some graphene composites have good removal effects on multiple heavy metals or pollutants. Therefore, the application fields and scope of these composites will be wider. And an in-depth study of their structure and properties will be more meaningful.

\section{Application of Graphene and Its Composites as Catalyst in Water Treatment}

Due to the unique physicochemical properties of graphene and its composites, they have been used as high-efficiency catalysts for the removal and degradation of environmental pollutants [46, 47]. In the general catalytic process, the surface atoms of the catalyst often play a decisive role in the catalytic reaction, while the internal atoms do not participate in the catalytic reaction [48]. However, in the graphene-based catalyst, the catalytic atoms were completely exposed, which greatly increased the contact between the catalytic atoms and the substrates, thereby maximizing the catalytic effect [49]. The Table 2 summarizes the basic information of graphene and its composites as catalysts.

Adsorption is the initial step of heterogeneous catalysis. Studies had shown that when graphene was used as the wall of carbon nanotubes [50]. The carbon nanotubes showed ultra-strong association with polycyclic aromatic hydrocarbons (PAHs) and metal because graphene is flatter and more ductile. In photocatalysis, the pollutant molecules were transferred from the solution to the surface of graphene and its composites. By the strong $\pi-\pi$ interaction between the molecules and graphene, the photoexcited electrons react rapidly with the $\mathrm{O}_{2}$ adsorbed on the materials to generate free radicals under illumination, so that more electrons and holes can be produced on the surface of the composites, thereby effectively improving the photocatalytic efficiency $[51,52]$. Also, in the presence of heteroatoms, such as nitrogen, boron, etc. the $\pi$ electron cloud of graphene and its composite materials 
Table 2. Graphene and its composite as catalysts.

\begin{tabular}{|c|c|c|c|c|}
\hline Materials & Preparation & Contaminant & Degradation ratio/rate & Ref \\
\hline $\begin{array}{c}\text { Three-dimensional grapheme } \\
\text { foam }\end{array}$ & Loading nZVI on porous & Azo dye orange IV & $94.50 \%$ & {$[58]$} \\
\hline \multirow{2}{*}{$\begin{array}{c}\text { Reduced GO/polyethyleneimine/ } \\
\text { Ag nanocomposite gel }\end{array}$} & \multirow{2}{*}{$\begin{array}{l}\text { Preparation of hydrogel using } \\
\text { polyethylene imine }\end{array}$} & Rhodamine B & Up to $100 \%$ & \multirow{2}{*}[59]{} \\
\hline & & Methylene blue & Up to $100 \%$ & \\
\hline $\mathrm{GO} \mathrm{TiO}_{2}$ photocatalysts & Liquid phase deposition method & $\begin{array}{l}\text { Mixture of diuron, alachlor, } \\
\text { isoproturon and atrazine }\end{array}$ & $8.2 \times 10^{-3} \mathrm{~mol} \cdot \mathrm{min}^{-1} \cdot \mathrm{g}^{-1}$ & [66] \\
\hline $\begin{array}{l}\text { Reduced GO-silver } \\
\text { nanocomposites }\end{array}$ & $\begin{array}{c}\text { Adding an appropriate amount of } \\
\mathrm{AgNO}_{3} \text { to the reduced } \mathrm{GO} \\
\text { dispersion system }\end{array}$ & $\begin{array}{l}\text { Pesticides and halocarbon } \\
\text { compounds }\end{array}$ & Up to $100 \%$ & [67] \\
\hline $\mathrm{Ag}_{3} \mathrm{PO}_{4}-\mathrm{GO}$ composite & Electrostatically driven method & $\begin{array}{l}\text { 2,4-Dichlorophenol }(2,4- \\
\text { DCP) }\end{array}$ & $55.91 \%$ & [68] \\
\hline $\begin{array}{l}\mathrm{GO} / \mathrm{Fe}_{3} \mathrm{O}_{4} \text {-horseradish peroxidase } \\
\text { binary enzyme catalyst catalyzes }\end{array}$ & $\begin{array}{c}\text { Ultrasonic-assisted reverse } \\
\text { co-precipitation method }\left(\mathrm{GO} / \mathrm{Fe}_{3} \mathrm{O}_{4}\right)\end{array}$ & 2,4-DCP & $93 \%$ & [69] \\
\hline $2 \mathrm{D} \gamma-\mathrm{MnO}_{2} / 2 \mathrm{D}$ rGO nano-hybrid & Hydrothermal method & 4-Nitrophenol & Up to $100 \%$ & [70] \\
\hline $\mathrm{TiO}_{2}$-graphene composite & Hydrothermal method & Bromate & $99 \%$ & [73] \\
\hline $\begin{array}{c}\mathrm{TiO}_{2} \text { nanowires } / \mathrm{Fe}_{2} \mathrm{O}_{3} \\
\text { nanoparticles/ GO sheets }\end{array}$ & $\begin{array}{l}\text { Hydrothermal, colloidal blending, } \\
\text { and vacuum filtration method }\end{array}$ & Humic acid & $98 \%$ & [76] \\
\hline
\end{tabular}

would be distorted, resulting in empty or additional orbitals to enhance catalyst performance $[53,54]$.

\section{Degradation of Dye Wastewater}

Organic dyes cannot be completely degraded, so they can cause pollution to be discharged into the environment with the wastewater. It has been the focus of many researchers on the efficient treatment of such pollutants and the recovery of catalysts in water.

Graphene and its derivatives have a strong $\pi-\pi$ stacked porous structure and excellent mechanical strength, which makes them ideal carriers for immobilizing various nanoparticles and provides ideal water/solid interface. And interconnecting porous structure enables the materials to be in full contact with organic dyes $[52,55]$. Among the many nanomaterials, nano-zero-valent iron (nZVI) has a larger specific surface area and higher reaction efficiency. However, nZVI has a high saturation magnetization, making it prone to aggregate. Loading nZVI on graphene and its composites not only solves the problem of easy aggregation, also protecting nZVI from rapid oxidation and facilitates the recovery of materials in water [56, 57]. Wei Wang et al. [58] prepared 3DG-Fe by loading nZVI on porous three-dimensional grapheme (3DG) foam. Because 3DG has a strong adsorption effect on the azo dye orange IV, when nZVI was supported on it, the effective collision between the active site of nZVI and the dye molecules can be significantly improved. The degradation rate of the azo dye orange IV can reach $94.5 \%$, while the removal rate by pure nZVI was only $70.5 \%$.

Tifeng Jiao et al. [59] used 3D graphene coagulation in the presence of polyethyleneimine (PEI) to reduce
GO. And silver acetate simultaneously in the hydrogel matrix were to prepare an RGO/PEI/Ag nanocomposite gel based on reduced graphene oxide (RGO). On the $\mathrm{RGO} / \mathrm{PEI} / \mathrm{Ag}$ nanocomposite gel, Ag was uniformly distributed on the RGO lamellae as the active site of photocatalysis, and the organic dues methylene blue (MB) and rhodamine $\mathrm{B}(\mathrm{RhB})$ have nearly $100 \%$ degradation effect under ultraviolet irradiation condition. It also has a catalytic effect in the dark, but the efficiency is reduced.

\section{Degradation of Persistent Organic Pollutants}

$\mathrm{TiO}_{2}$ nanofibers have the large specific surface area and high porosity, which provide more active sites for the adsorption, resulting in a more effective photocatalytic process [60]. Many studies have demonstrated that $\mathrm{GO}-\mathrm{TiO}_{2}$ composites have excellent catalytic performance [61-65]. Marta Cruz et al. [66] prepared a graphene-based $\mathrm{GO}-\mathrm{TiO}_{2}$ composite catalyst. Studies have shown that under visible light conditions, the catalyst has great degradation effect for the mixture of diuron, alachlor, isoproturon and atrazine, and the degradation rate can reach $8.2 \times 10^{-3} \mathrm{~mol} \cdot \mathrm{min}^{-1} \cdot \mathrm{g}^{-1}$. In addition, the degradation of pollutants can still achieve the desired results in natural water. A novel reduced graphene oxide-silver nanocomposites (RGO@Ag) can first degrade the pesticides and halocarbon compounds in water by $\mathrm{Ag}$ nanoparticles, and then adsorb the reaction products onto the RGO plate through $\pi-\pi$ interaction to achieve the desired treatment effect of the target contaminants [67]. Moreover, the composite material has good regeneration performance and opens up a new direction for removing persistent organic pollutants in water. 
$\mathrm{Ag}_{3} \mathrm{PO}_{4}$ is a photocatalyst with excellent performance. To solve the slight solubility of $\mathrm{Ag}_{3} \mathrm{PO}_{4}$ in solution and the photo-induced corrosion caused by the band structure, Xiaojuan Chen et al. [68] prepared $\mathrm{Ag}_{3} \mathrm{PO}_{4}-\mathrm{GO}$ composite photocatalyst to degrade 2,4-dichlorophenol (2,4-DCP). And the specific surface area of $\mathrm{Ag}_{3} \mathrm{PO}_{4}-\mathrm{GO}$ composite photocatalyst increases with the increase of $\mathrm{GO}$ addition. The $\mathrm{O}_{2}$ adsorbed on GO generates free radicals under the action of photogenerated electrons, and the electron transport speed is very fast because of the good conductivity of GO, which makes the composite exhibit excellent visible-light photocatalytic activity and stability compared with pure $\mathrm{Ag}_{3} \mathrm{PO}_{4}$. About $55.91 \%$ of the 2, 4-DCP or intermediates were mineralized under 60 minutes of irradiation. Jia Huang et al. [69] prepared a composite of artificially simulated enzyme-like catalysts $\left(\mathrm{GO} / \mathrm{Fe}_{3} \mathrm{O}_{4}\right)$ using graphene oxide and nano$\mathrm{Fe}_{3} \mathrm{O}_{4}$. Combining artificial simulated enzyme-like catalyst with the natural enzyme horseradish peroxidase (HRP) as a binary enzyme catalyst catalyzes the oxidation 2,4-DCP with a removal rate of $93 \%$. The removal rate was higher than that of 2, 4-DCP using $\mathrm{HRP}$ or $\mathrm{GO} / \mathrm{Fe}_{3} \mathrm{O}_{4}$ alone. The binary enzyme catalyst showed good catalytic stability. Research showed that strong electrostatic interaction and hydrogen bond were the main interaction forces between the oxygencontaining functional groups of GO and the surface amino acid residues of HRP, which was also the key to improving the catalytic performance.

Yuxian Wang et al. [70] synthesized 2D $\gamma-\mathrm{MnO}_{2} / 2 \mathrm{D}$ rGO nano-hybrid $\left(\mathrm{MnO}_{2} / \mathrm{rGO}\right)$ using two-dimensional reduced graphene oxide (2D rGO) hydrothermal method, and 2D/2D hybrid materials were applied to catalytic ozonation of 4-nitrophenol for the first time. The catalytic efficiency of $\mathrm{MnO}_{2} / \mathrm{rGO}$ was much higher than that of $\mathrm{MnO}_{2}$ or $\mathrm{rGO}$ alone. Among them, rGO was considered to promote the transfer of electrons. The quenching test showed that oxygen radicals $\mathrm{O}_{2}$-and $1 \mathrm{O}_{2}$ play a major role in the degradation of 4-nitrophenol. Moreover, $2 \mathrm{D} \mathrm{MnO}_{2} / \mathrm{rGO}$ catalyst has good stability.

\section{Other Applications}

Bromate $\left(\mathrm{BrO}_{3}^{-}\right)$, which has carcinogenicity and genotoxicity, was an inevitable toxic by-product in the process of ozone disinfection in drinking water, which is carcinogenic and genotoxic [71, 72]. Xin Huang et al. [73] prepared $\mathrm{TiO}_{2}$-graphene composite (P25-GR) photocatalyst for the degradation of $\mathrm{BrO}_{3}^{-}$. The excited photogenerated electrons rapidly flowed to graphene, effectively separating electron-holes pairs and preventing charge recombination, thereby improving the catalytic efficiency of $\mathrm{TiO}_{2}$. The test results of photoluminescence spectra (PL) also support this conclusion. The highest degradation rate of $\mathrm{BrO}_{3}^{-}$by P25-GR photocatalyst was $99 \%$, which was significantly higher than that of P25 alone [74].
Membrane fouling caused by natural organic compounds such as humic acid is one of the main obstacles to the wide application of membrane technology in water treatment [75]. A composite membrane composed of $\mathrm{TiO}_{2}$ nanowires $/ \mathrm{Fe}_{2} \mathrm{O}_{3}$ nanoparticles/GO sheets was used to remove humic acid with a removal rate of up to $98 \%$ [76]. In natural water, $\mathrm{TiO}_{2}$ is negatively charged or neutral, so it cannot adsorb the same negatively charged humic acid, resulting in a lack of effective contact, and the photocatalytic effect were greatly reduced. Nano$\mathrm{Fe}_{2} \mathrm{O}_{3}$ has a strong adsorption effect on humic acid, which enhanced the effective contact between the adsorbent and the adsorbate. The promotion of charge separation by GO film solved the problem of electronhole pair recombination in $\mathrm{TiO}_{2}$. Therefore, the $\mathrm{Fe}_{2} \mathrm{O}_{3}$ nanoparticle and GO film together enhanced the photocatalytic activity of the film. The appearance of this film has promoted the practical application of the future photocatalytic film in water treatment.

\section{Conclusions}

Graphene's excellent properties make it widely used in water treatment. However, the use of graphene alone has a toxic effect on organisms due to its fineness and difficulty in separating it from the water. To solve those problems, through modifying and compounding graphene with other materials, researchers have prepared more excellent materials, such as aerogels, magnetic materials, etc. by modifying graphene or combining with other materials. These materials were widely used in the treatment of heavy metal wastewater, persistent organic pollutants, dye wastewater, oily wastewater and other wastewater as adsorbents and catalysts.

These novel water treatment materials with good pollution treatment effect, regeneration performance and stability have wide application and development value in the future. Although graphene and its composite materials have a large adsorption capacity, the adsorption process often required harsh conditions such as ultraviolet light irradiation, specific $\mathrm{pH}$ to achieve the desired effects. Besides, in the natural water, the same catalytic efficiency as laboratory experiments cannot be achieved. The resolution of those problems in the future will enable this new type of materials to obtain a wider range of application and scope.

\section{Acknowledgements}

This work was supported by the National Natural Science Foundation of China (No. 41501514), The Fundamental Research Funds for the Central Universities (No. N172304046; N182303031); The Natural Science Foundation of Hebei Province, China (No. D2019501004; B2014501053); the Opening 
Foundation of Ministry of Education Key Laboratory of Pollution Processes and Environmental Criteria (No. 201903); Key research and development program of Hebei Province, China (No. 19224204D).

\section{Conflict of Interest}

The authors declare no conflict of interest.

\section{References}

1. KS N., AK G., SV M. Electric Field Effect in Atomically Thin Carbon Films. Science, 306 (5696), 666, 2004.

2. LU H., LI S.-D. Two-dimensional carbon allotropes from graphene to graphyne. Journal of Materials Chemistry C, 1 (23), 3677, 2013

3. NATH BHATTARAI L. Graphene: A Peculiar Allotrope Of Carbon. Himalayan Physics, 3, 87, 2013.

4. SUR U.K. Graphene: A Rising Star on the Horizon of Materials Science. International Journal of Electrochemistry, 2012, 12, 2012.

5. LEE W., KIM Y., LEE M Y., OH J.H., LEE J.U. Highly stretchable fiber transistors with all-stretchable electronic components and graphene hybrid electrodes. Organic Electronics, 69, 320, 2019.

6. HU X., MU L., WEN J., ZHOU Q. Immobilized smart RNA on graphene oxide nanosheets to specifically recognize and adsorb trace peptide toxins in drinking water. Journal of Hazardous Materials, 213-214, 387, 2012.

7. TANG Y., CHEN W., ZHANG H., SHEN Z., ZHAO G., DAI X. Modulating the electronic structures and sensing properties of metal and non-metal atoms modified graphene sheets. Physica E: Low-dimensional Systems and Nanostructures, 111, 206, 2019.

8. CHENG C., XIAO F., WANG Y., TANG R., PEI H. Graphene Modified Fe-Si@C/Graphene Composite Anode Material. Materials Reports, 33 (18), 3005, 2019 [In Chinese].

9. HU X., ZHOU Q. Health and Ecosystem Risks of Graphene. Chemical Reviews, 113 (5), 3815, 2013.

10. HU S., LOZADA-HIDALGO M., WANG F., MISHCHENKO A., SCHEDIN F., NAIR R., HILL E., BOUKHVALOV D., KATSNELSON M., DRYFE R. Proton transport through one-atom-thick crystals. Nature, 516 (7530), 227, 2014

11. SHAHIL K.M.F., BALANDIN A.A. Thermal properties of graphene and multilayer graphene: Applications in thermal interface materials. Solid State Communications, 152 (15), 1331, 2012.

12. JIANG X., YANG X., ZHU Y., SHEN J., FAN K., LI C. In situ assembly of graphene sheets-supported $\mathrm{SnS} 2$ nanoplates into 3D macroporous aerogels for highperformance lithium ion batteries. Journal of Power Sources, 237, 178, 2013.

13. ZHOU Q., HU X. Systemic Stress and Recovery Patterns of Rice Roots in Response to Graphene Oxide Nanosheets. Environmental Science \& Technology, 51 (4), 2022, 2017.

14. ZHU Y., MURALI S., CAI W., LI X., SUK J., POTTS J., RUOFF R. ChemInform Abstract: Graphene and Graphene Oxide: Synthesis, Properties, and Applications. Advanced materials (Deerfield Beach, Fla.), 22, 3906, 2010.
15. MARCANO D.C., KOSYNKIN D.V., BERLIN J.M., SINITSKII A., SUN Z., SLESAREV A., ALEMANY L.B., LU W., TOUR J.M. Improved Synthesis of Graphene Oxide. ACS Nano, 4(8), 4806-4814, 2010.

16. XU J., WANG L., ZHU Y. Decontamination of Bisphenol A from Aqueous Solution by Graphene Adsorption. Langmuir, 28 (22), 8418, 2012.

17. ROBATI D., MIRZA B., RAJABI M., MORADI O., TYAGI I., AGARWAL S., GUPTA V. Removal of hazardous dyes-BR 12 and methyl orange using graphene oxide as an adsorbent from aqueous phase. Chemical Engineering Journal, 284, 687, 2016

18. CHEN H., GAO B., LI H. Removal of sulfamethoxazole and ciprofloxacin from aqueous solutions by graphene oxide. Journal of Hazardous Materials, 282, 201, 2015.

19. DENG J., YU K., XIAO G., XIE J. Research progress in the treatment of heavy metal wastewater by adsorption. Industrial Water Treatment, 34 (11), 4, 2014 [In Chinese].

20. ZHOU Q., WANG M. Adsorption-desorption characteristics and pollution behavior of reactive $\mathrm{X}-3 \mathrm{~B}$ red dye in four Chinese typical soils. Journal of Soils and Sediments, 10 (7), 1324, 2010.

21. REN N., ZHOU X., GUO W., YANG S. A review on treatment methods of dye wastewater. CIESC Journal, 64 (01), 84, 2013 [In Chinese].

22. MITTERSTEINER M., SCHMITZ F., BARCELLOS I O. Reuse of dye-colored water post-treated with industrial waste: Its adsorption kinetics and evaluation of method efficiency in cotton fabric dyeing. Journal of Water Process Engineering, 17, 181, 2017.

23. SUN Y., YANG M., YU F., CHEN J., MA J. Synthesis of Graphene Aerogel Adsorbents and Their Applications in Water Treatment. Progress in Chemistry, 27 (8), 1133, 2015 [In Chinese].

24. CHEN L., LI Y., DU Q., WANG Z., XIA Y., YEDINAK E., LOU J., CI L. High performance agar/graphene oxide composite aerogel for methylene blue removal. Carbohydrate Polymers, 155, 345, 2017.

25. YANG M., LIU X., QI Y., SUN W., MEN Y. Preparation of $\kappa$-carrageenan/graphene oxide gel beads and their efficient adsorption for methylene blue. Journal of Colloid and Interface Science, 506, 669, 2017.

26. DUMAN O., TUN S., POLAT T.G., BOZOĞLAN B.K. Synthesis of magnetic oxidized multiwalled carbon nanotube-к-carrageenan-Fe3O4 nanocomposite adsorbent and its application in cationic Methylene Blue dye adsorption. Carbohydrate Polymers, 147, 79, 2016.

27. YANG S.-T., CHEN S., CHANG Y., CAO A., LIU Y., WANG H. Removal of methylene blue from aqueous solution by graphene oxide. Journal of Colloid and Interface Science, 359 (1), 24, 2011.

28. SAHRAEI R., SEKHAVAT POUR Z., GHAEMY M. Novel magnetic bio-sorbent hydrogel beads based on modified gum tragacanth/graphene oxide: Removal of heavy metals and dyes from water. Journal of Cleaner Production, 142, 2973, 2017.

29. FU Y.-C., YANG H.-R., ZHANG J., FENG L. Research progress of oil-bearing wastewater treatment by adsorption technology. Applied Chemical Industry, 46 (10), 2035, 2017 [In Chinese].

30. LIU T., HUANG M., LI X., WANG C., GUI C.-X., YU Z.-Z. Highly compressible anisotropic graphene aerogels fabricated by directional freezing for efficient absorption of organic liquids. Carbon, 100, 456, 2016.

31. GE J., SHI L.-A., WANG Y.-C., ZHAO H.-Y., YAO H.-B., ZHU Y.-B., ZHANG Y., ZHU H.-W., WU H.-A., YU S.-H. 
Joule-heated graphene-wrapped sponge enables fast cleanup of viscous crude-oil spill. Nature Nanotechnology, 12, 434, 2017.

32. SI Y., YU J., TANG X., GE J., DING B. Ultralight nanofibre-assembled cellular aerogels with superelasticity and multifunctionality. Nature Communications, 5, 5802, 2014.

33. MI H-Y., JING X., POLITOWICZ A.L., CHEN E., HUANG H.-X., TURNG L.-S. Highly compressible ultralight anisotropic cellulose/graphene aerogel fabricated by bidirectional freeze drying for selective oil absorption. Carbon, 132, 199, 2018.

34. ZHANG F., LI J., TAN J., WANG B., HUANG F. Advance of the treatment of heavy metal wastewater by adsorption. Chemical Industry and Engineering Progress, 11, 2749, 2013 [In Chinese].

35. XU R., ZHOU G., TANG Y., CHU L., LIU C., ZENG Z., LUO S. New double network hydrogel adsorbent: Highly efficient removal of $\mathrm{Cd}(\mathrm{II})$ and $\mathrm{Mn}(\mathrm{II})$ ions in aqueous solution. Chemical Engineering Journal, 275, 179, 2015.

36. LIANG Q., LUO H., GENG J., CHEN J. Facile one-pot preparation of nitrogen-doped ultra-light graphene oxide aerogel and its prominent adsorption performance of $\mathrm{Cr}(\mathrm{VI})$. Chemical Engineering Journal, 338, 62, 2018.

37. ZHOU G., LIU C., TANG Y., LUO S., ZENG Z., LIU Y., XU R., CHU L. Sponge-like polysiloxane-graphene oxide gel as a highly efficient and renewable adsorbent for lead and cadmium metals removal from wastewater. Chemical Engineering Journal, 280, 275, 2015.

38. SINGH D.K., KUMAR V., MOHAN S., HASAN S.H. Polylysine Functionalized Graphene Aerogel for the Enhanced Removal of $\mathrm{Cr}(\mathrm{VI})$ through Adsorption: Kinetic, Isotherm, and Thermodynamic Modeling of the Process. Journal of Chemical \& Engineering Data, 62 (5), 1732, 2017.

39. JIAO C., XIONG J., TAO J., XU S., ZHANG D., LIN H., CHEN Y. Sodium alginate/graphene oxide aerogel with enhanced strength-toughness and its heavy metal adsorption study. International Journal of Biological Macromolecules, 83, 133, 2016.

40. WANG L., BAI C., ZHU Z. Adsorption properties and mechanism of $\mathrm{Pb}(\mathrm{II})$ ions adsorbed by graphene oxide/ sodium alginate composite membrane. Acta Materiae Compositae Sinica, 1, 2019 [In Chinese].

41. HU X.-J., LIU Y.-G., WANG H., CHEN A.-W., ZENG G.-M., LIU S.-M., GUO Y.-M., HU X., LI T.-T., WANG Y.-Q., ZHOU L., LIU S.-H. Removal of $\mathrm{Cu}(\mathrm{II})$ ions from aqueous solution using sulfonated magnetic graphene oxide composite. Separation and Purification Technology, 108, 189, 2013.

42. CUI L., WANG Y., GAO L., HU L., YAN L., WEI Q., DU B. EDTA functionalized magnetic graphene oxide for removal of $\mathrm{Pb}(\mathrm{II}), \mathrm{Hg}(\mathrm{II})$ and $\mathrm{Cu}(\mathrm{II})$ in water treatment: Adsorption mechanism and separation property. Chemical Engineering Journal, 281, 1, 2015.

43. TAN P., SUN J., HU Y., FANG Z., BI Q., CHEN Y., CHENG J. Adsorption of $\mathrm{Cu}^{2+}, \mathrm{Cd}^{2+}$ and $\mathrm{Ni}^{2+}$ from aqueous single metal solutions on graphene oxide membranes. Journal of Hazardous Materials, 297, 251, 2015.

44. FANG F., KONG L., HUANG J., WU S., ZHANG K., WANG X., SUN B., JIN Z., WANG J., HUANG X.-J., LIU J. Removal of cobalt ions from aqueous solution by an amination graphene oxide nanocomposite. Journal of Hazardous Materials, 270, 1, 2014.

45. DINDA D., KUMAR SAHA S. Sulfuric acid doped poly diaminopyridine/graphene composite to remove high concentration of toxic $\mathrm{Cr}(\mathrm{VI})$. Journal of Hazardous Materials, 291, 93, 2015.

46. HAN S., HU L., LIANG Z., WAGEH S., AL-GHAMDI A.A. CHEN Y., FANG X. One-step hydrothermal synthesis of 2D hexagonal nanoplates of $\alpha-\mathrm{Fe}_{2} \mathrm{O}_{3}$ /graphene composites with enhanced photocatalytic activity. Advanced Functional Materials, 24 (36), 5719, 2014.

47. HUíZAR-FÉLIX A.M., AGUILAR-FLORES C., MARTÍNEZ-DE-LA CRUZ A., BARANDIARÁN J.M., SEPÚLVEDA-GUZMÁN S., CRUZ-SILVA R. Removal of Tetracycline Pollutants by Adsorption and Magnetic Separation Using Reduced Graphene Oxide Decorated with $\alpha-\mathrm{Fe}_{2} \mathrm{O}_{3}$ Nanoparticles. Nanomaterials, 9 (3), 313, 2019.

48. KONSTANTINOU I.K., ALBANIS T.A. $\mathrm{TiO}_{2}$-assisted photocatalytic degradation of azo dyes in aqueous solution: kinetic and mechanistic investigations: A review. Applied Catalysis B: Environmental, 49 (1), 1, 2004.

49. ALBERO J., GARCIA H. Doped graphenes in catalysis. Journal of Molecular Catalysis A Chemical, 408, 296, 2015.

50. PERERA S.D., MARIANO R.G., VU K., NOUR N., SEITZ O., CHABAL Y., BALKUS Jr K.J. Hydrothermal Synthesis of Graphene-TiO ${ }_{2}$ Nanotube Composites with Enhanced Photocatalytic Activity. ACS Catalysis, 2 (6), 949, 2012.

51. DU J., LAI X., YANG N., ZHAI J., KISAILUS D., SU F., WANG D., JIANG L. Hierarchically ordered macromesoporous $\mathrm{TiO}_{2}$-graphene composite films: improved mass transfer, reduced charge recombination, and their enhanced photocatalytic activities. ACS nano, 5 (1), 590, 2010.

52. WANG C., ZHANG X. Preparation and photocatalytic properties of three-dimensional graphene/porous black $\mathrm{TiO}_{2}$ composites. Journal of Dalian Polytechnic University, 38 (1), 32-35, 2019 [In Chinese].

53. YE B., LEE M., JEONG B., KIM J., LEE D.H., BAIK J.M., KIM H.-D. Partially reduced graphene oxide as a support of $\mathrm{Mn}-\mathrm{Ce} / \mathrm{TiO}_{2}$ catalyst for selective catalytic reduction of $\mathrm{NO}_{x}$ with $\mathrm{NH}_{3}$. Catalysis Today, 328, 300, 2019.

54. CHEN D., HE Z., PEI S.-E., HUANG L.-A., SHAO H., JIN Y., WANG J. Pd nanoparticles supported on $\mathrm{N}$ and $\mathrm{P}$ dual-doped graphene as an excellent composite catalyst for methanol electro-oxidation. Journal of Alloys and Compounds, 785, 781, 2019.

55. WANG Z., LIU Z., CHEN J., YANG H., LUO J., GAO J., ZHANG J., YANG C., JIA S., LIU B. Self-assembly of three-dimensional CdS nanosphere/graphene networks for efficient photocatalytic hydrogen evolution. Journal of Energy Chemistry, 31, 34, 2019.

56. YANG B., TIAN Z., ZHANG L., GUO Y., YAN S. Enhanced heterogeneous Fenton degradation of Methylene Blue by nanoscale zero valent iron (nZVI) assembled on magnetic $\mathrm{Fe}_{3} \mathrm{O}_{4}$ /reduced graphene oxide. Journal of Water Process Engineering, 5, 101, 2015.

57. REN L., DONG J., CHI Z., HUANG H. Reduced graphene oxide-nano zero value iron (rGO-nZVI) micro-electrolysis accelerating $\mathrm{Cr}$ (VI) removal in aquifer. Journal of environmental sciences, 73, 96, 2018.

58. WANG W., CHENG Y., KONG T., CHENG G. Iron nanoparticles decoration onto three-dimensional graphene for rapid and efficient degradation of azo dye. Journal of Hazardous Materials, 299, 50, 2015.

59. IAO T., GUO H., ZHANG Q., PENG Q., TANG Y., YAN X., LI B. Reduced Graphene Oxide-Based Silver Nanoparticle-Containing Composite Hydrogel as Highly 
Efficient Dye Catalysts for Wastewater Treatment. Scientific reports, 5, 11873, 2015.

60. LAERA G., JIN B., ZHU H., LOPEZ A. Photocatalytic activity of $\mathrm{TiO}_{2}$ nanofibers in simulated and real municipal effluents. Catalysis Today, 161 (1), 147, 2011.

61. PASTRANA-MARTÍNEZ L.M., MORALES-TORRES S., LIKODIMOS V., FIGUEIREDO J.L., FARIA J.L., FALARAS P., SILVA A.M. Advanced nanostructured photocatalysts based on reduced graphene oxide$\mathrm{TiO}_{2}$ composites for degradation of diphenhydramine pharmaceutical and methyl orange dye. Applied Catalysis B: Environmental, 123, 241, 2012.

62. LI H., CUI X. A hydrothermal route for constructing reduced graphene oxide/ $\mathrm{TiO}_{2}$ nanocomposites: enhanced photocatalytic activity for hydrogen evolution. International Journal of Hydrogen Energy, 39 (35), 19877, 2014.

63. WANG F., ZHANG K. Reduced graphene oxide-TiO, nanocomposite with high photocatalystic activity for the degradation of rhodamine B. Journal of Molecular Catalysis A: Chemical, 345 (1), 101, 2011.

64. YANG W.-D., LI Y.-R., LEE Y-C. Synthesis of r-GO/TiO, composites via the UV-assisted photocatalytic reduction of graphene oxide. Applied Surface Science, 380, 249, 2016.

65. JIANG G., LIN Z., CHEN C., ZHU L., CHANG Q., WANG N., WEI W., TANG $\mathrm{H}$. $\mathrm{TiO}_{2}$ nanoparticles assembled on graphene oxide nanosheets with high photocatalytic activity for removal of pollutants. Carbon, 49 (8), 2693, 2011.

66. CRUZ M., GOMEZ C., DURAN-VALLE C.J., PASTRANA-MARTÍNEZ L.M., FARIA J.L., SILVA A.M.T., FARALDOS M., BAHAMONDE A. Bare $\mathrm{TiO}_{2}$ and graphene oxide $\mathrm{TiO}_{2}$ photocatalysts on the degradation of selected pesticides and influence of the water matrix. Applied Surface Science, 416, 1013, 2017.

67. KOUSHIK D., SEN GUPTA S., MALIYEKKAL S.M., PRADEEP T. Rapid dehalogenation of pesticides and organics at the interface of reduced graphene oxide-silver nanocomposite. Journal of Hazardous Materials, 308, 192, 2016.
68. CHEN X.-J., DAI Y.-Z., WANG X.-Y., GUO J., LIU T.-H., LI F.-F. Synthesis and characterization of $\mathrm{Ag}_{3} \mathrm{PO}_{4}$ immobilized with graphene oxide (GO) for enhanced photocatalytic activity and stability over 2,4-dichlorophenol under visible light irradiation. Journal of Hazardous Materials, 292, 9, 2015.

69. HUANG J., CHANG Q., DING Y., HAN X., TANG H. Catalytic oxidative removal of 2,4-dichlorophenol by simultaneous use of horseradish peroxidase and graphene oxide $/ \mathrm{Fe}_{3} \mathrm{O}_{4}$ as catalyst. Chemical Engineering Journal, 254, 434, 2014.

70. WANG Y., XIE Y., SUN H., XIAO J., CAO H., WANG S. 2D/2D nano-hybrids of $\gamma-\mathrm{MnO}_{2}$ on reduced graphene oxide for catalytic ozonation and coupling peroxymonosulfate activation. Journal of Hazardous Materials, 301, 56, 2016.

71. WU Q., MENG F., ZHANG J., GUO W. Formation, Detection and Control of Bromate in the Ozone Disinfection of Drinking Water. China Water \& Wastewater, 22 (16), 12, 2006 [In Chinese].

72. WANG W., JIANG S., ZHU H., WANG Y., YANG Y. Study on the Genotoxicty of Bromate. Journal of Environment and Health, 20 (3), 137, 2003 [In Chinese].

73. HUANG X., WANG L., ZHOU J., GAO N. Photocatalytic decomposition of bromate ion by the UV/P25-Graphene processes. Water Research, 57, 1, 2014.

74. ZHANG X., ZHANG T., NG J., PAN J., SUN D. Transformation of Bromine Species in $\mathrm{TiO}_{2}$ Photocatalytic System. Environmental Science \& Technology, 44 (1), 439, 2010.

75. LI Z., XU S., LI S. Membrane fouling and cleaning during microfiltration and ultrafiltration. TECHNOLOGY OF WATER TREATMENT, 23 (4), 187, 1997 [In Chinese].

76. RAO G., ZHANG Q., ZHAO H., CHEN J., LI Y. Novel titanium dioxide/iron (III) oxide/graphene oxide photocatalytic membrane for enhanced humic acid removal from water. Chemical Engineering Journal, 302, 633-640, 2016. 